\title{
Discussion on Establishment of Education Brand of Higher Vocational Art Design
}

\author{
Hui Qin \\ Art Design Department \\ Jiyuan Vocational and Technical College \\ Jiyuan, China
}

\begin{abstract}
Based on the characteristics of the times of vigorously carrying forward the spirit of the craftsman and building Chinese brand, this paper aims at the development and current situation of art design education in higher vocational education, elaborates the problems existing in art design education in terms of practical level, work creation, teaching form and management, and expounds the necessity of inheriting the spirit of craftsman and building education brand. Combined with the teaching practice, this paper suggests the unity of knowledge and action and focuses on practice; inherits classics and advocates original works; changes ideas and builds professional education brands.
\end{abstract}

Keywords-the spirit of craftsman; professional brand; studio teaching; unity of knowledge and action

\section{INTRODUCTION}

Art design major is one of the most common majors in all colleges and universities in China. With the change of people's thoughts and the continuous reform and implementation of quality education, schools and parents has already begun to cultivate the comprehensive quality of the students from the primary school even the kindergarten, and art basically has become the required tutorial content for each child. In the face of higher school, it can also be chosen according to the learning condition and specialty and hobby of the children. Furthermore, the introduction of art is relatively easy and it does not require the innate talents, considering the universality of application and complexity of employment and entrepreneurship after graduation, the number of people who choose to learn art design major is also increasing. However, the art design major is an inter-discipline with strong comprehensiveness and covers a number of professional fields. Due to the limitations and stiffness of teaching management, or the teaching model copying foreign experience that can not completely comply with the over-all situation and job requirements of domestic education, it can not meet the learning needs and skill requirements of each major of art design.

\section{THE DEVELOPMENT AND CURRENT SitUATION OF HighER VOCATIONAL ART DESIGN EDUCATION}

As a symbol of the birth of modern design education, Bauhaus has deeply affected the education and development of modern design in the world. Three points in the design education theory of Bauhaus should be mentioned: the first is that technology and art should be in harmony and unity; the second is that artists, entrepreneurs and technicians should work closely together; the third is that school assignments of students shall be closely connected with enterprise project. The design concept makes the modern design change from idealism to realism; therefore, modern art design pays more attention to whether the design works can be made into finished products with the appropriate materials under the existing technology to meet the demands of people. Besides, it also clearly points out attention should be paid to the content of art design education in higher vocational colleges, which is also the basic educational concept of applied undergraduate art design education.

The objective of higher vocational education is to cultivate highly skilled and applied talents. Higher vocational art design major should enable the students to master the job skills, focus on the comprehensive application of relative knowledge, meanwhile, pay attention to cultivating the students' expressive ability, communication and cooperation, attach importance to the practical knowledge, strengthen the training for vocational skills, introduce the actual project into the classroom, achieve the seamless joint of classroom and the company, corporate with employment education, entrepreneurship education and universal education, let students make full use of the specialized characteristics of employment and easy entrepreneurship and equip students with employment and entrepreneurship ability through the professional study. At present, the main problems existing in the education of higher vocational art design major are:

\section{A. The Characteristics of Higher Vocational Education Are Not Fully Played and the Practical Ability Needs to Be Improved}

Higher vocational education is a significant constituent part of higher education in China; the state gradually pays attention to the higher vocational education from the promulgation of Decision of the State Council on Vigorously Promoting the Reform and Development of Higher Vocational Education. The target of higher vocational education is to cultivate the skilled talents and pay attention to the skill-oriented and professional talent. The target of higher vocational art design major is to cultivate the designers who serve for the industries that are front-line in social production and have closely 
relations with people' life. Although the major has been improved and developed continuously, however, due to lack of mature experience, the pertinence of objective of personnel cultivation is not strong enough, and the characteristics of higher vocational education are not fully played. In addition, teachers' resources are still based on education background and job title, and the personnel cultivation of higher vocational education still stays in a dilemma affected by construction fund and enrollment quality. After graduation, students still need a process of adaptation, growth and learning to formally enter into the job, and the employment rate has declined after a year of graduation.

\section{B. The Originality in Design Works Is Not Enough and the Original Works Are Relative Less}

In the daily teaching process, especially in the design process of teaching cases and after-class assignments, the original works are relatively less or the original parts in a single work are less. The artistic works are lack of pertinence and creativity, and the inheritance for traditional culture is not enough, therefore, the works have lost the originality, uniqueness and individuality of the art design works. However, it's not just in teaching process. In China, many "ODM" (Original Design Manufacturer) companies are still running. ODM finishes the job by itself from design to production, and the finished products will be brought by OEM Party. However, in order to make a quick profit from the process, many designs will be simply modified and then sold to different OEM Parties, so their brand value will be reduced. Therefore, whether the innovation and originality education of art design education in higher vocational or in other colleges and universities in China shall be attached importance to and changed under the background that China advocates to build "Chinese brand".

\section{The Teaching Form Is Not Flexible and Teaching Management Is Not Unified}

As the multi-disciplinary comprehensive major, art design major is limited by major setup and teaching management and its teaching form is not flexible. For example, students of art require the small-class teaching in the teaching process, so the teacher-student ratio shall be suitable for 1:15. However, it is difficult to carry out small-class teaching for engineering higher vocational colleges or the calculation of teacher's workload will be unfairly quantified in the small-class teaching. For example, if the administrative class has no more than 30 students, its 1 class hour will be calculated as 0.8 class hour; there are some deviations between practical teaching and practical teaching of engineering. At present, there are no unified and mature management standards or instructions for art major education. Moreover, the courses that have strong practicalness do not arrange the cooperative enterprise when arranging the teaching places, and it needs the teachers to repeatedly apply for changing the teaching place in the later period. However, affected by low season and peak season of industry, the same courses of some majors will have different effects in various time.

\section{THE NECESSITY OF BUILDING EDUCATION BRAND}

\section{A. Building Brand Needs the Spirit of Craftsman}

In recent years, the modern apprenticeship system has become a kind of education model for higher vocational education and needs schools and enterprises to jointly cultivate students in the school system. With continuous exploration and accumulation and test of reform, higher vocational art design education have equipped with the cultivating mode of university-enterprise cooperation and work-study combination. Conducting modern apprenticeship system can improve the rationality, pertinence and advantage in the teaching process of art design major, enhance the level of practical skills of graduates, who can adapt themselves to the needs of enterprise's post and achieve the successful employment or entrepreneurship.

The art design major mainly includes graphic art design, interior design, costume design, animation design and other majors. In addition to the basic hand drawing teaching, the compulsively main courses of these majors have the learning of computer software in giving lessons, and practical courses account for a large proportion. To ensure that the students can apply what they have learned, the software teaching must be closely combined with practical teaching. The premise that how to turn the computer design drawing into reality is that the designer shall clearly understand what his design content is and what technology and material he can use to ensure the finished material object and to reach the best optimal effect, otherwise, this design will lose its actual application value and not worth a cent, therefore, it needs the designers to understand technology application and material. Take interior design of environmental art design for example, whether a set of AutoCAD drawing can be used depends on the existing technology and material of the society, therefore, the construction technology and decorative material are the subject content that the students must learn. In that way, the application of water, electricity, heating, security and protection, new trend and smart home is a multidisciplinary integrated application process, and students can plunge into learning the needed content by following the master worker to look, learn and make in the process of actual construction. In the same way, both the package design and costume design need to make pasteboard pattern and examples and then to produce, which requires the cognition and master for the technology and material.

In the process of technique teaching in the practical link, the students should not only learn but also master the knowledge. Carrying forward the spirit of the craftsman requires the professional ethics that love what you do, stick to original intention, keep persistence and concentration, abandon fickleness and pursue best and most perfect. During the art design education, it shall also pay special attention to innovation education, however, innovation education is not just creativity, but also the activity that applies the modern technology to create objects based on the originality. This requires us that we should not only teach the technology in the process of art design education, but also pay attention to the transfer of concentration, patience and perseverance of the spirit of craftsman. "Only the painstaking endeavor can make 
exquisite craftsmanship, do not worry about the success." When everyone does education with the spirit of craftsman and keeps the perseverance, building education brand will not be an armchair strategist.

\section{B. Education Needs To Establish A Brand}

Briefly speaking, brand is the cognition degree of the public to the product and is a kind of evaluation and cognition for an enterprise and product, service and value, and it is a kind of trust. The brand corresponds to the market, and the education brand corresponds to the talent market. The enhancement of professional competitiveness requires more research orientation, training mode and market research for modern education. With the approach of the era of Internet and knowledge economy, after continuous expansion of several years, the scale of students in higher vocational education has greatly increased, and the demand of the whole social development for higher vocational students is gradually changing from the quantity demand to the quality demand, which requires us to continuously improve the education quality of higher vocational art design. Moreover, with the openness of higher education system and the establishment of application-oriented universities, the cultivation channel of high technology applied talents has been toward the diversified development. Although the art students are fewer than students of cultural course, their entrance requirements are favorable. Higher vocational art design major will face the dual pressure and competition of the source market of students and the employment market of the graduates, therefore, improving the quality and professional popularity of art design education in higher vocational colleges is extremely urgent.

\section{SugGestions ON BUILDING ARt Design MAJOR BRAND}

\section{A. Accomplish the Unity of Knowledge and Action and Focus on Practice}

The so-called "the unity of knowledge and action" not only can equip the students with professional theory and professional quality, but also can make students learn the skills of craftsman. The development of the industry roundly and permanently promotes the higher vocational art design education, and will also affect the reform of professional courses, especially the higher vocational curriculum system based on job demands. And the curriculum reform must be carried out through the teachers at front-line teaching. To cultivate the professionals with the unity of knowledge and action, firstly, it requires the teachers of higher vocational art design major to equip with multidisciplinary comprehensive knowledge, scientific design philosophy and advanced design thought, meanwhile, they should constantly improve their selfcultivation and professional skill, stick to putting on field practice in the enterprise and factory, get centralized training and industry research, positively establish studio, undertake actual project, timely update the educational concept, grasp the development trend of major, equip with proficient and accurate practical operation skills, ensure that the teaching is not separated from industry reality and professional skills do not fall behind the social skills and guarantee the effect of practical teaching in the process of professional teaching.
The popularization and promotion of studio teaching model and modern apprenticeship system break the traditional teaching model and achieve the connection of classroom teaching and actual project, even though the students can enter into the enterprise and finish the production required by professional skills to actually realize the unity of knowledge and action. For example, in furniture design, the students are not only required to accurately draw the corresponding design drawings, but also required to use woodworking technology and traditional handicraft to finish the designed works, on this point, the foreign professional education do a good job, which is worth for us to borrow from and learn.

\section{B. Inherit Classics and Advocate Original Works}

The broad and profound Chinese traditional culture is widely enjoyed by designers at home and abroad, as the college teaching staff, teachers should pay attention to the cultivation of the humanistic quality and edification of traditional culture for the students in the education of art design major, advocate originality and actually lead the students to create the design works and products with Chinese characteristics and national features.

The studio teaching model mentioned above is a kind of practice way. In the studio, the teacher is the master worker, and the student is the apprentice. The art design studio not only helps the students to improve their practical ability, but also provides the teachers with a platform to study the industry and market. The teachers not only lead the students to participate in the project, but also bring his project result into the classroom, which actually realizes the teaching situation of teaching, learning and researching. Moreover, the practical skills of teachers and student teams have been improved, and with the help of studio platform, they can make product research, take the heart of the craftsman to make more original works and products, and build the professional brand. However, how art design studio to better run, serve society and teaching still needs our continuous exploration and promotion.

\section{Change Ideas and Build Brands}

Ministry of Education will support and construct the highquality higher vocational and technical colleges which have accurate positioning, distinct specialized characteristic, strongly social service ability, leading comprehensive level of running the university, high integrating degree with the needs of local economic and social development and prominent industrial advantage. The high vocational colleges also put forward "guaranteeing quality, building connotation, establishing brand", with the help of the advantages, the art design major should open the schooling thought, be flexible in teaching management, build education brand, improve the professional competitiveness and popularity, make students positively participate in and the industry urgently to employ. To establish brand is to build characteristics. Each college has its own characteristic specialty, allowing students to definitely know which brand schools they can choose when they choose their majors. It brings with many benefits to build a brand in society, industry, school and family.

Meanwhile, it still needs to pay attention to the propaganda and operation of brand. In fact, propaganda is one of the job 
content involved in art design major. From the image design to the advertising copy, all of them belong to the category of art design. For example, Peking University is the top education brand in the liberal arts school, while Tsinghua University is the top of the science school. In terms of vocational education, the propaganda of Shandong Lanxiang Vocational School and New Oriental make the best. At least, their propaganda gives us a deep understanding of its brand features. If all colleges and universities create their own brand, they will be more effective to divert their students and protect students' enthusiasm and interest in professional learning.

\section{CONCLUSION}

Government Work Report in 2017 pointed out that "we will promote workmanship and foster a culture of workmanship where workers have a strong work ethic and tirelessly seek improvement. We will refine our incentive mechanisms and see great numbers of Chinese workers exemplify workmanship and more Chinese brands enjoy international recognition. We will usher in an era of quality for economic development in China." As the educators of high vocational art design major, they should build originality and cultivate craftsmen, greatly promote the spirit of the craftsman, constantly enhance the professionally practical skills, improve the professional teaching model, make accurately professional training objective, positively participate in the education quality engineering construction team, be responsible for their students, sincerely cooperate with students, build the specialized characteristic, establish professional brand and academy brand, devote their original intention to the educational business and the heart of craftsman to seek after the best, so as to actually realize their original intention to cultivate high-skilled talents to ensure the employment rate of high vocational art design major.

\section{REFERENCES}

[1] Zhang Ju. Design Education Advocates the Spirit of Craftsman[J], Art and Literature for the Masses, September, 2016.

[2] Zhang Zhenfeng. Research on the Cultivation of Core Competitiveness of Brand Specialty in Higher Vocational Colleges[J], Hebei Vocational Education, February, 2017.

[3] Wang Jiarong. Analysis of Current Situation and Exploration of Teaching Model for Art Design Education in Colleges and Universities, Modern Vocational Education, March, 2017.

[4] Yue Lin. The Present Situation and Prospect of Art Design Education from the Perspective of Creative Thinking[J], Art Science and Technology, October, 2017. 